Floodplain/Wetlands Assessment for the Borrow Areas for the Restoration of the Weldon Spring Quarry, Weldon Spring Site, Missouri

Environmental Assessment Division Argonne National Laboratory

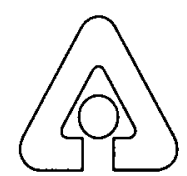

Operated by The University of Chicago, under Contract W-31-109-Eng-38, for the 


\section{Argonne National Laboratory}

Argonne National Laboratory, with facilities in the states of Illinois and Idaho, is owned by the United States Government, and operated by the University of Chicago under the provisions of a contract with the Department of Energy.

This technical memo is a product of Argonne's Environmental Assessment Division (EAD). For information on the division's scientific and engineering activities, contact:

Director, Environmental Assessment Division

Argonne National Laboratory

Argonne, Illinois 60439-4815

Telephone (630) 252-3107

Presented in this technical memo are preliminary results of ongoing work or work that is more limited in scope and depth than that described in formal reports issued by the $E A D$.

Publishing support services were provided by Argonne's Information and Publishing Division (for more information, see IPD's home page: http://www.ipd.anl.gov/).

\section{Disclaimer}

This report was prepared as an account of work sponsored by an agency of the United States Government. Neither the United States Government nor any agency thereof, nor The University of Chicago, nor any of their employees or officers, makes any warranty, express or implied, or assumes any legal liability or responsibility for the accuracy, completeness, or usefulness of any information, apparatus, product, or process disclosed, or represents that its use would not infringe privately owned rights. Reference herein to any specific commercial product, process, or service by trade name, trademark, manufacturer, or otherwise does not necessarily constitute or imply its endorsement, recommendation, or favoring by the United States Government or any agency thereof. The views and opinions of document authors expressed herein do not necessarily state or reflect those of the United States Government or any agency thereof, Argonne National Laboratory, or The University of Chicago. 


\section{Floodplain/Wetlands Assessment for the Borrow Areas for the Restoration of the Weldon Spring Quarry, Weldon Spring Site, Missouri}

by R.A. Van Lonkhuyzen

Environmental Assessment Division

Argonne National Laboratory, 9700 South Cass Avenue, Argonne, Illinois 60439 
This report is printed on recycled paper. 


\section{CONTENTS}

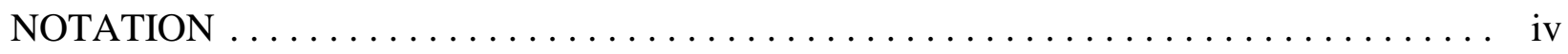

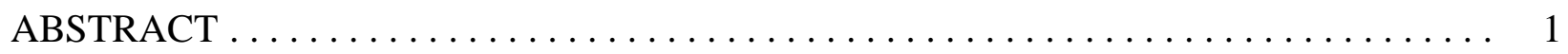

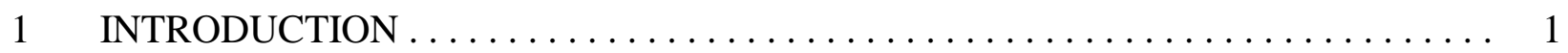

2 DESCRIPTIONS OF THE PROPOSED ACTION AND ALTERNATIVES $\ldots \ldots \ldots .5$

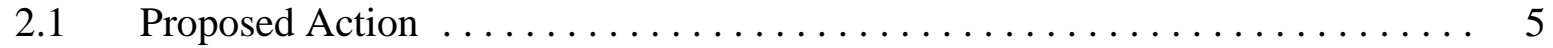

$2.2 \quad$ Alternative Sources of Fill Material $\ldots \ldots \ldots \ldots \ldots \ldots \ldots \ldots \ldots \ldots$

$2.3 \quad$ No Action Alternative $\ldots \ldots \ldots \ldots \ldots \ldots \ldots \ldots \ldots \ldots \ldots \ldots \ldots$

3 DESCRIPTIONS OF FLOODPLAINS AND WETLANDS OF THE

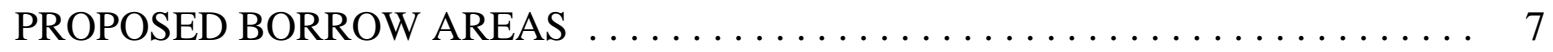

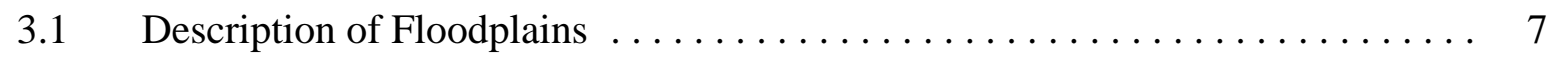

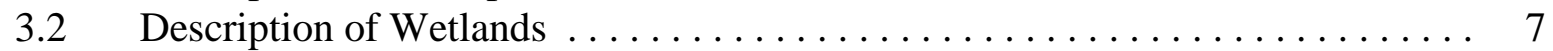

4 ANTICIPATED IMPACTS TO FLOODPLAINS AND WETLANDS $\ldots \ldots \ldots \ldots \ldots$

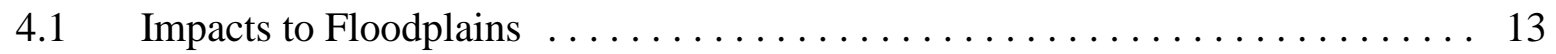

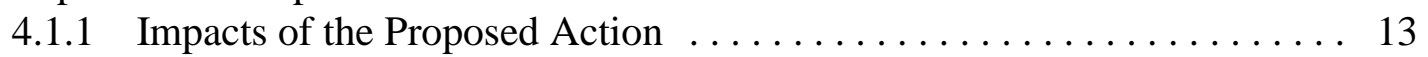

4.1.2 Impacts of the No Action Alternative .................... 13

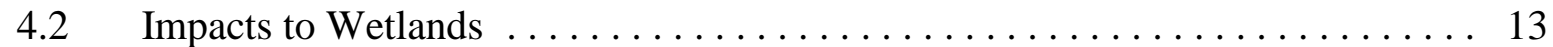

4.2.1 Impacts of the Proposed Action ....................... 13

4.2.2 Impacts of the No Action Alternative $\ldots \ldots \ldots \ldots \ldots \ldots \ldots \ldots \ldots \ldots$

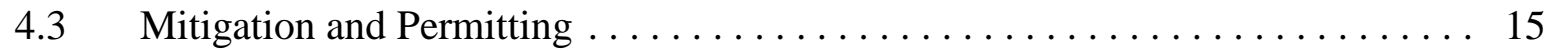

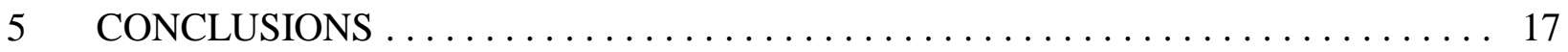

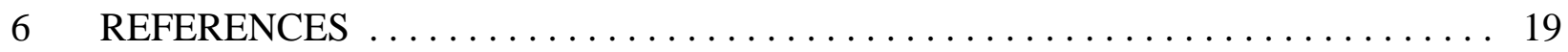

\section{FIGURES}

$1 \quad$ Location of the Weldon Spring Quarry $\ldots \ldots \ldots \ldots \ldots \ldots \ldots \ldots \ldots \ldots \ldots \ldots \ldots$

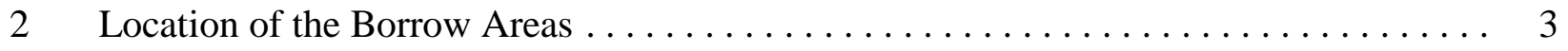

3 Wetlands in the Vicinity of the Primary Borrow Area $\ldots \ldots \ldots \ldots \ldots \ldots \ldots \ldots$

4 Wetlands in the Vicinity of the Second Borrow Area $\ldots \ldots \ldots \ldots \ldots \ldots \ldots \ldots$ 


\section{NOTATION}

The following is a list of the acronyms, initialisms, and abbreviations (including units of measure) used in this report.

\section{ACRONYMS, INITIALISMS, AND ABBREVIATIONS}

$\begin{array}{ll}\text { AMSL } & \text { above mean sea level } \\ \text { CFR } & \text { Code of Federal Regulations } \\ \mathrm{cm} & \text { centimeter(s) } \\ \text { CWA } & \text { Clean Water Act } \\ \text { DOE } & \text { U.S. Department of Energy } \\ \text { FEMA } & \text { Federal Emergency Management Agency } \\ \mathrm{ft} & \text { foot (feet) } \\ \mathrm{ft}^{2} & \text { square foot (feet) } \\ \mathrm{ha} & \text { hectare(s) } \\ \mathrm{in} . & \text { inch(es) } \\ \mathrm{km} & \text { kilometer(s) } \\ \mathrm{m} & \text { meter(s) } \\ \mathrm{m}^{2} & \text { square meter(s) } \\ \mathrm{m}^{3} & \text { cubic meter(s) } \\ \mathrm{mi}^{3} & \text { mile(s) } \\ \mathrm{NWI} & \text { National Wetlands Inventory } \\ \mathrm{USFWS}^{3} & \text { U.S. Fish and Wildlife Service } \\ \mathrm{yd}^{3} & \text { cubic yard(s) }\end{array}$




\title{
FLOODPLAIN/WETLANDS ASSESSMENT FOR THE BORROW AREAS FOR THE RESTORATION OF THE WELDON SPRING QUARRY, WELDON SPRING SITE, MISSOURI
}

by

\author{
R.A. Van Lonkhuyzen
}

\begin{abstract}
The U.S. Department of Energy proposes to develop two soil borrow areas, 8.1 ha (20 acres) and 1.3 ha (3.1 acres) in size, near the Weldon Spring Site, Weldon Spring, Missouri. One wetland and portions of four others would be excavated during development of the borrow areas. These wetlands include palustrine emergent and palustrine forested wetland types and total 0.98 ha (2.4 acres). Hydrology and biotic communities may be altered in several wetlands located near the borrow areas. No long-term adverse impacts to floodplains are expected.
\end{abstract}

\section{INTRODUCTION}

The U.S. Department of Energy (DOE) is conducting a reclamation project at the Weldon Spring Quarry in Missouri. The reclamation project is being performed to attain final closure and the desired final configuration of the quarry and its immediate surrounding areas after completion of remediation activities conducted under the requirements of the Comprehensive Environmental Response, Compensation, and Liability Act (CERCLA), as amended.

The Weldon Spring Quarry, along with the Weldon Spring Chemical Plant, constitute the Weldon Spring Site, which is located in St. Charles County, Missouri, about $48 \mathrm{~km}$ (30 mi) west of St. Louis (Figure 1). Processing and disposal activities between the 1940s and 1960s resulted in radioactive and chemical contamination at the site. The Weldon Spring Site is included on the National Priorities List of the U.S. Environmental Protection Agency. At the Weldon Spring Quarry, remediation activities, which included removal of contaminated bulk material and soil and decontamination of all exposed surfaces, were completed in October 1995, fulfilling the requirements of CERCLA. 


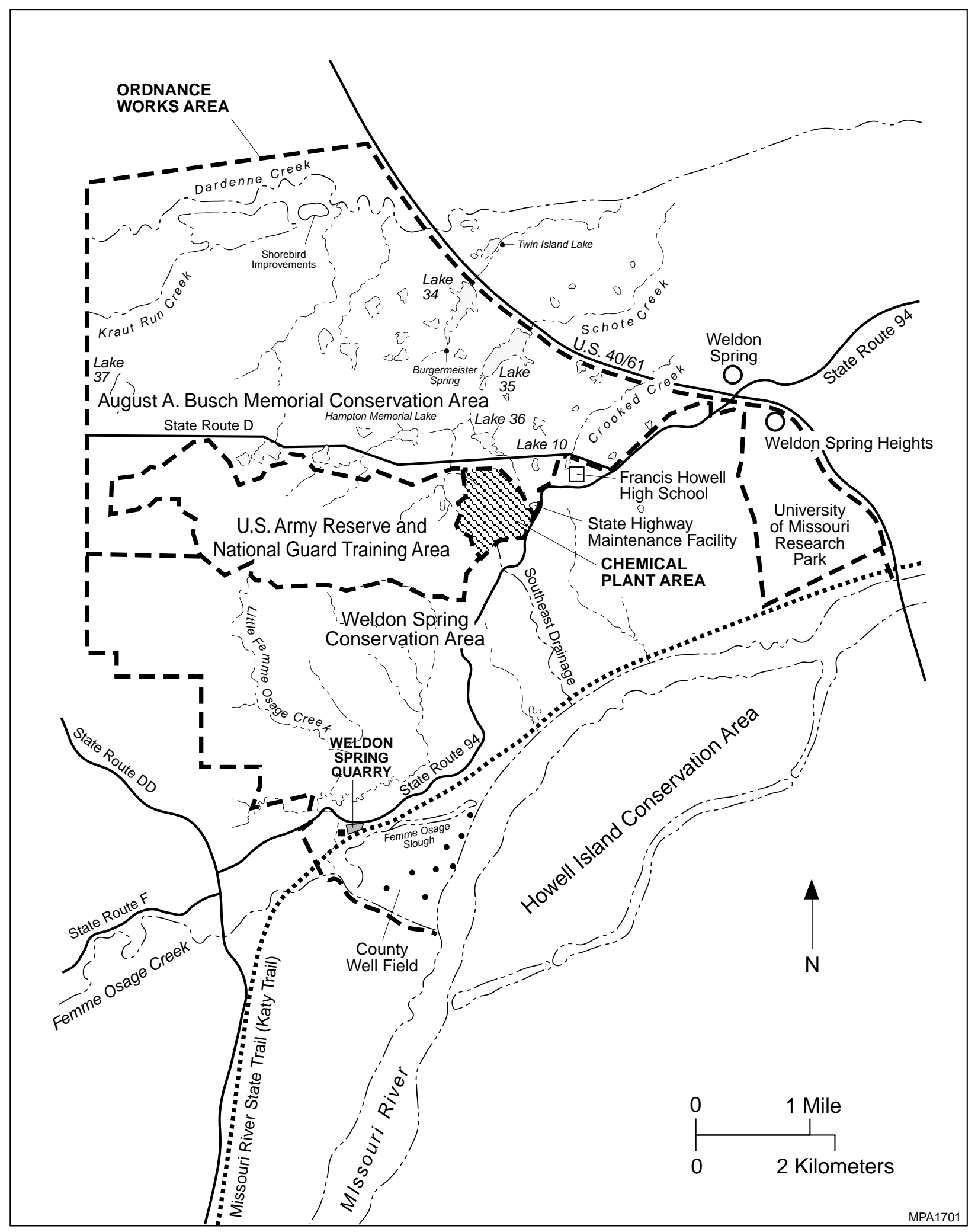

FIGURE 1 Location of the Weldon Spring Quarry 
For the reclamation of the quarry proper, a soil borrow area would be developed near the quarry (Figure 2) as the source for low-permeability fill material. A second borrow area would be developed as a contingency, if the primary area could not be fully utilized because of unanticipated circumstances such as flooding. This fill material is needed for backfilling the remediated but open quarry; the final configuration of the quarry is expected to minimize physical hazards associated with an open quarry, as well as prevent further ponding of water in the quarry sump.

This floodplain/wetlands assessment evaluates the potential impacts to floodplains and wetlands from the proposed development of the borrow areas. The assessment has been prepared in accordance with Executive Order 11988, Floodplain Management, and Executive Order 11990, Protection of Wetlands, and with DOE guidance and policy (Title 10, Code of Federal Regulations, Part 1022 [10 CFR Part 1022]) for compliance with these executive orders.

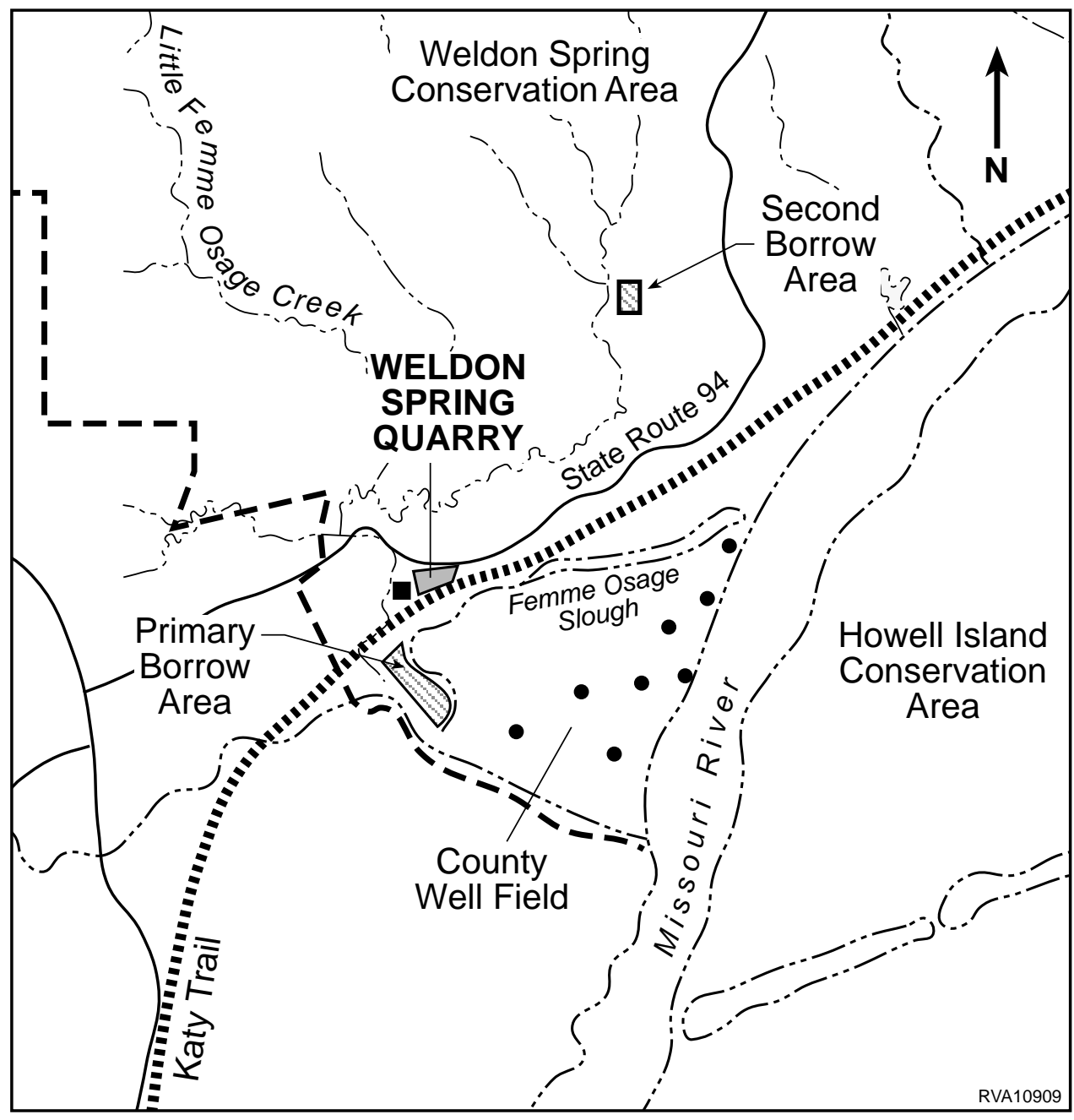

FIGURE 2 Location of the Borrow Areas 


\section{DESCRIPTIONS OF THE PROPOSED ACTION AND ALTERNATIVES}

\subsection{PROPOSED ACTION}

Approximately $86,400 \mathrm{~m}^{3}\left(113,000 \mathrm{yd}^{3}\right)$ of uncontaminated fill material would be required to backfill the Weldon Spring Quarry. Approximately 42,000 $\mathrm{m}^{3}\left(55,000 \mathrm{yd}^{3}\right)$ of this material is required to be low-permeability fill. Under the proposed action, DOE would develop a soil borrow area near the quarry as the source of the fill material. A second borrow area would be developed if necessary. The primary area proposed for the excavation of borrow material is about 8.1 ha (20 acres) in size and is located approximately $0.37 \mathrm{~km}(0.23 \mathrm{mi})$ southwest of the quarry, within the State of Missouri Weldon Spring Conservation Area. This proposed borrow area is bounded by Femme Osage Creek, Femme Osage Slough, and Little Femme Osage Creek and is approximately $1.2 \mathrm{~km}(0.77 \mathrm{mi})$ from the Missouri River. The topography of this region, which is within the Missouri River floodplain, is relatively flat. Elevations within the proposed borrow area range from 139 to $141 \mathrm{~m}$ (455 to $462 \mathrm{ft}$ ) above mean sea level (AMSL). A levee, approximately $3 \mathrm{~m}$ ( $9 \mathrm{ft}$ ) high, extends along the northwest and southwest margins of the area of excavation and separates the borrow area from Femme Osage Creek and Little Femme Osage Creek. A 15-m (50-ft) buffer strip would be preserved between the excavation area and the margin of Femme Osage Slough, on the east side of the borrow area. Soils would be removed to a depth of approximately $2.4 \mathrm{~m}(8 \mathrm{ft})$. A haul road would be constructed from the borrow area to the quarry, across the Katy Trail, a recreational trail that passes through the area.

A second area proposed for excavation of fill material is located approximately $1.7 \mathrm{~km}$ $(1.1 \mathrm{mi})$ northeast of the quarry and is also within the Weldon Spring Conservation Area. This area would be held as a contingency and would be developed only if the primary borrow area could not be fully utilized because of unanticipated circumstances such as flooding. This proposed borrow area

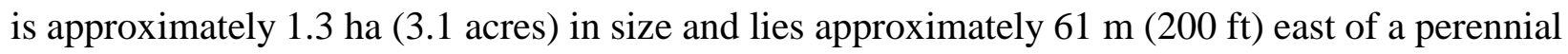
tributary of Little Femme Osage Creek. Topography in this area ranges from relatively flat floodplain areas along perennial streams, to rolling hills and steep ravines. Elevations within the borrow area range from 152 to $158 \mathrm{~m}$ (500 to $519 \mathrm{ft})$. A hill, rising to $180 \mathrm{~m}(590 \mathrm{ft})$, borders this borrow area

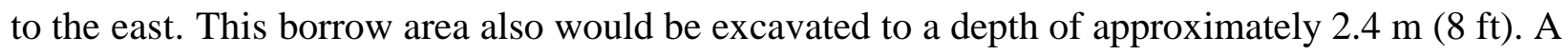
haul road would be constructed partially within an existing electric transmission line right-of-way. The right-of-way extends along the west margin of the borrow area and runs south to the former haul road for the quarry.

Good engineering practices would be employed to control erosion and sedimentation to downstream surface waters and adjacent areas. Erosion controls, such as hay bales and silt fences, would be installed down gradient from all excavations to prevent the transport of silt downstream by storm water flows. Following project completion, the borrow areas would remain as open excavations and would likely become areas of surface water and groundwater accumulation. Outer 
portions of the excavated area would be gently to moderately sloped (not to exceed 1:3), and steep or vertical slopes would be avoided. Wetland characteristics, including hydrophytic vegetation communities, subsequently may develop within these areas.

\subsection{ALTERNATIVE SOURCES OF FILL MATERIAL}

The excavation of borrow material from other areas was examined as an alternative to the proposed action. Alternative sources of fill material were identified but eliminated as suitable locations because of (1) impacts to cultural resources in two potential borrow areas near the quarry, and (2) a substantial increase in the cost of transporting fill material from a previously developed borrow area east of the Weldon Spring Site and approximately $5.5 \mathrm{~km}$ (3.4 mi) from the quarry.

\subsection{NO ACTION ALTERNATIVE}

Under the No Action Alternative, the quarry would not be backfilled, and the physical hazards associated with an open quarry and ponded water would remain. 


\section{DESCRIPTIONS OF FLOODPLAINS AND WETLANDS OF THE PROPOSED BORROW AREAS}

\subsection{DESCRIPTION OF FLOODPLAINS}

The 100-year floodplain of the Missouri River is relatively flat and extends to the base of the escarpment immediately northwest of the Katy Trail (FEMA 1992). The proposed primary borrow area would be located entirely within the 100-year floodplain, while the second borrow area would be outside the floodplain. The development of a borrow area in the floodplain is proposed because of the need for adequate quantities of fill material, primarily low-permeability material, in the vicinity of the quarry. Sources of material outside the floodplain are unsuitable because of other impacts or cost (see Section 2.2).

The 100-year flood elevation in the vicinity of the proposed borrow area is approximately $145 \mathrm{~m}$ (474 ft) AMSL. Femme Osage Slough and the St. Charles County well field are located within the floodplain and to the east of the primary borrow area. Surface elevations of the well field range from approximately 138 to $141 \mathrm{~m}$ (451 to $462 \mathrm{ft}$ ) AMSL. A levee (elevation approximately $143 \mathrm{~m}$ [470 ft] AMSL) is located along the Missouri River and borders the county well field, extending northwest along Femme Osage Creek and Little Femme Osage Creek to the Katy Trail. The levee is designed to reduce the frequency of flooding within the well field, although inundation of the well field occurred in 1989, 1993, 1994, and 1995. Floodplain soil in the vicinity of the borrow area is Waldron Silty Clay (Tummons 1982), which is classified as a mesic aeric fluvaquent. Typically these soils are somewhat poorly drained, with rare flooding for brief durations (Tummons 1982).

The dominant vegetation of the Missouri River floodplain in the project area consists of agricultural fields interspersed with deciduous forest. Forest communities in the vicinity of the primary borrow area are riparian and occur along the Missouri River, its tributaries, and Femme Osage Slough. Tree species include silver maple, green ash, box elder, cottonwood, and sycamore. The existing vegetation of the proposed area of excavation consists primarily of agricultural crops. The southeast portion of this borrow area contains a small wooded area; however, most of the trees have died as a result of extensive flooding from 1993 to 1995.

\subsection{DESCRIPTION OF WETLANDS}

Surveys were conducted during the spring and summer of 1999 to determine the presence of wetlands in or near the proposed borrow areas and haul routes (Figures 3 and 4). Wetland surveys included the delineation of jurisdictional wetlands that are regulated under Section 404 of the Clean Water Act (CWA). Jurisdictional wetlands are defined by the presence of hydric soil, wetland 


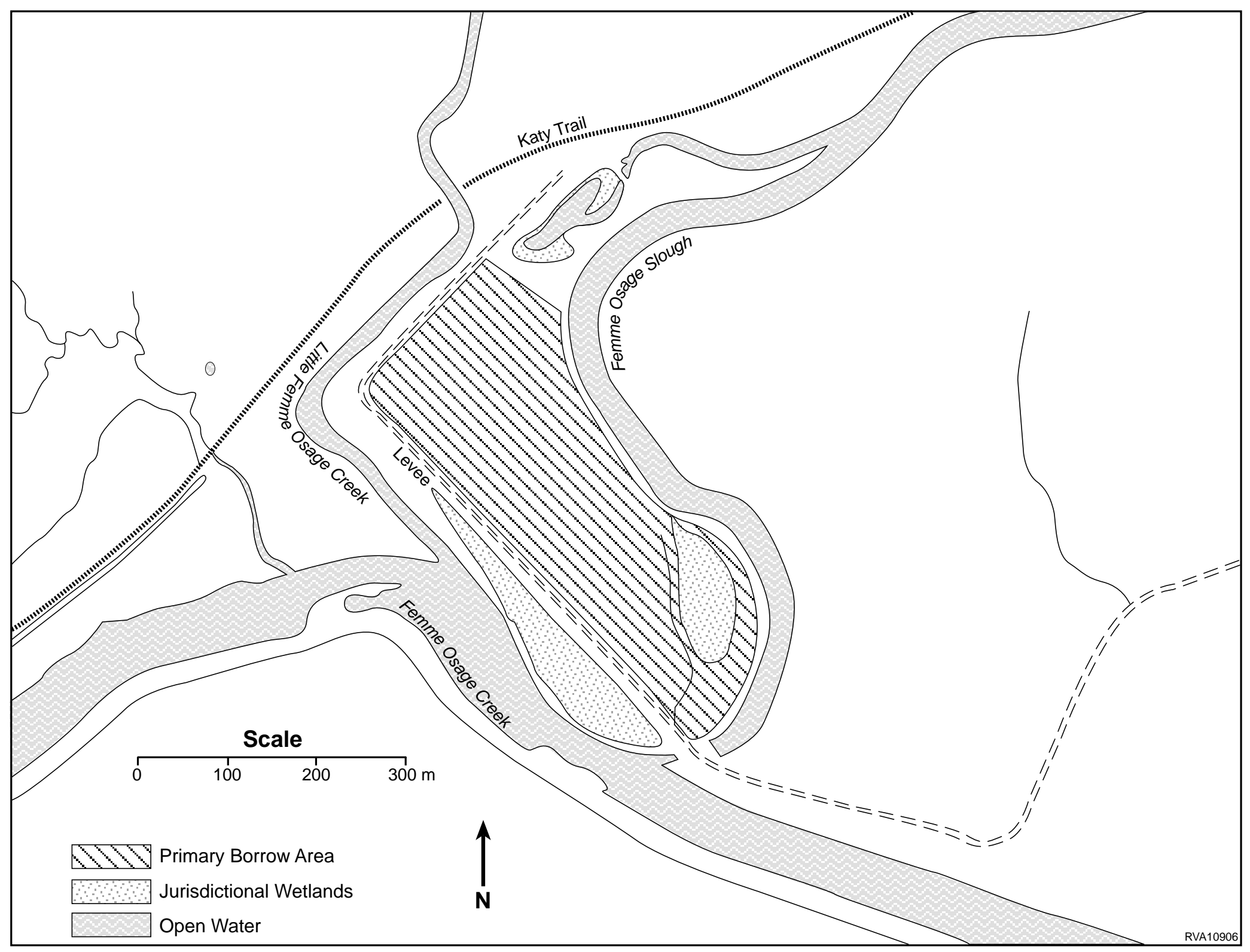

FIGURE 3 Wetlands in the Vicinity of the Primary Borrow Area 


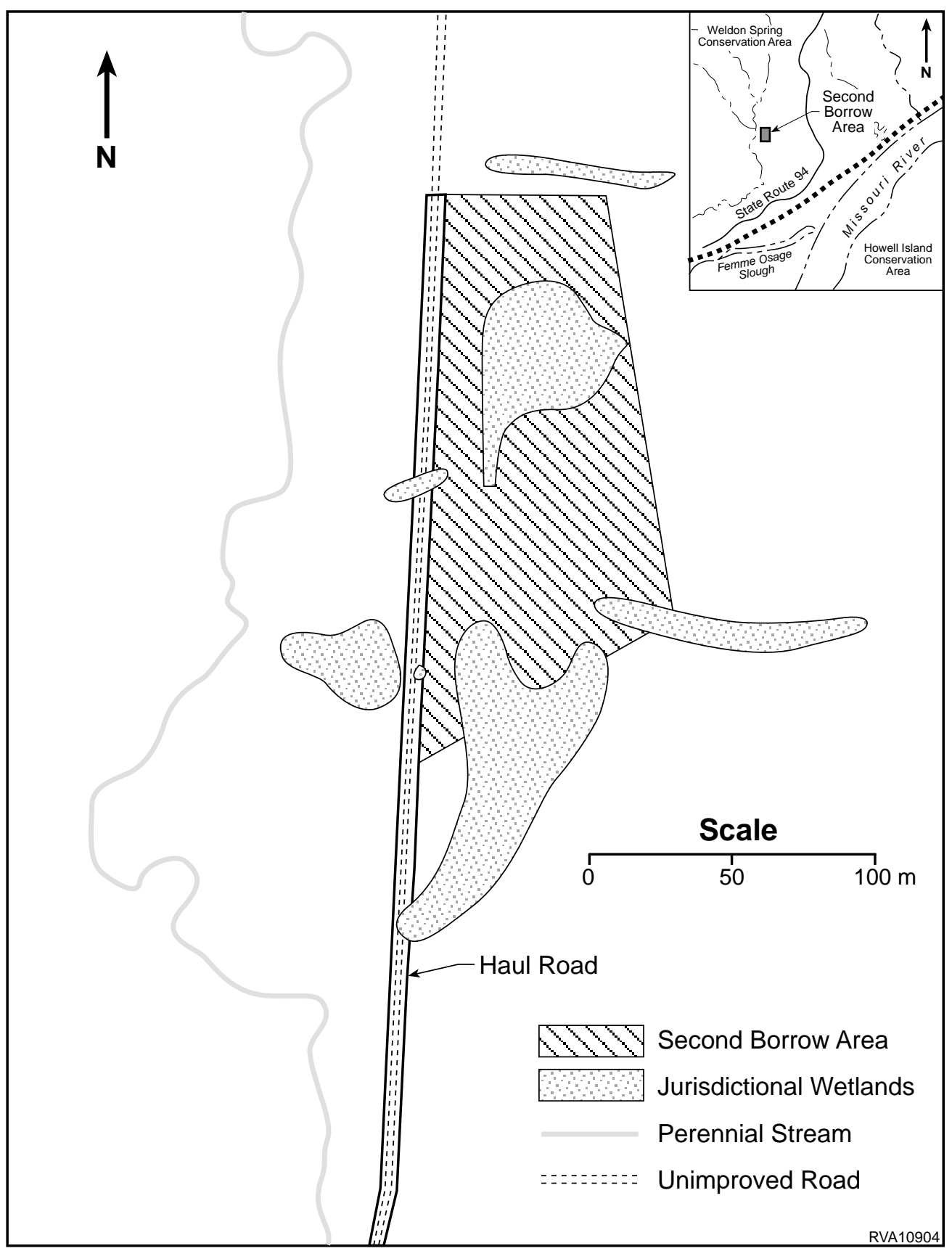

FIGURE 4 Wetlands in the Vicinity of the Second Borrow Area 
hydrology, and a vegetation community dominated by hydrophytic species (Environmental Laboratory 1987).

The southeast portion of the primary borrow area contains one jurisdictional wetland, 0.69 ha ( 1.7 acres) in size. This wetland is typically inundated by shallow surface water for extended periods early in the growing season; no surface water is present by mid- to late summer. The hydrological sources for this wetland consist of groundwater discharge and surface water flow. During the spring, the surface water of the wetland usually becomes continuous with the surface water of Femme Osage Slough. Water levels in the slough are controlled by the Missouri Department of Conservation. High water levels are typically maintained to facilitate fishing. The dominant vegetation within the wetland area consists of hydrophytic species and includes silver maple, black willow saplings, box elder saplings, green ash saplings, rice cut grass, beggars ticks, smartweed, monkeyflower, and giant ragweed. This wetland is a palustrine forested (dead) wetland that is seasonally flooded (Cowardin et al. 1979). The primary borrow area lies within the floodplain of the Missouri River, and most of the trees in this wetland and adjacent areas died several years prior to this survey because of flooding. A number of mature and sapling trees remain scattered throughout the wetland and immediately surrounding area; the canopy cover, however, is very open. This wetland is included in a larger area, along the margin of the slough, classified by the National Wetlands Inventory (NWI) as palustrine forested, broad-leaved deciduous, and temporarily flooded (USFWS 1989). No state or federally listed threatened, endangered, or rare species have been found or are expected to occur in this wetland area.

Soils in the area, including the primary borrow area and nearby wetlands, are identified as Waldron Silty Clay (Tummons 1982), which are slowly permeable soils. A fluctuating, perched high water table typically occurs at a depth of 0.30 to $1 \mathrm{~m}$ ( 1 to $3 \mathrm{ft}$ ) in winter, spring, and early summer in Waldron soil (Tummons 1982). The groundwater level recorded in a borehole located within the borrow area was at a depth of $2.3 \mathrm{~m}(7.5 \mathrm{ft})$ in November 1998. Saturated soil was located at $28 \mathrm{~cm}$ (11 in.) deep in April 1999 and at $20 \mathrm{~cm}$ (8 in.) deep in May 1999 at two locations within the borrow area, approximately $15.2 \mathrm{~m}$ (50 ft) from Femme Osage Slough.

Several wetlands also occur near the borrow area. A 1.2-ha (3.0-acre) jurisdictional wetland lies above the bank of Femme Osage Creek to the west of the borrow area and is separated from the borrow area by a levee. This wetland is a palustrine forested, broad-leaved deciduous wetland that is temporarily to seasonally flooded. It is classified as temporarily flooded by the NWI. The dominant woody species of the vegetation community are mature green ash, silver maple, black willow, cottonwood, and sandbar willow. This wetland receives surface water from flooding of Femme Osage Creek and other sources and is also likely an area of groundwater discharge. A natural ridge, approximately $1.7 \mathrm{~m}(5.5 \mathrm{ft})$ high, extends along the top of the creek bank at the margin of the wetland and contributes to the retention of surface water within the wetland. 
Femme Osage Slough, the former streambed of Femme Osage Creek, lies to the east of the borrow area (a 15-m [50-ft] buffer would remain between the area of excavation and the slough). The slough is a palustrine, unconsolidated bottom, permanently flooded wetland identified by the NWI as an unconsolidated bottom, lower perennial riverine wetland that is permanently flooded (USFWS 1989). The slough has steep banks along most of its perimeter and is unvegetated. Consequently, the area of the slough in the vicinity of the borrow area is not a jurisdictional wetland. However, the slough would be classified as "waters of the U.S." and, thus, is protected under Section 404 of the CWA.

A 0.49-ha (1.2-acre) wetland area is located adjacent to the slough just northeast of the borrow area. This wetland consists of 0.2 ha $(0.6$ acre $)$ of palustrine emergent wetland encircling 0.2 ha $(0.6$ acre $)$ of palustrine unconsolidated bottom wetland. The hydrological sources for this wetland include surface water received from Femme Osage Slough and the surrounding area, as well as groundwater discharge. The surface water in this wetland is separated from the slough by only a narrow partition of woody debris and soil. The dominant species of the emergent community include floating seedbox, water plantain, spike rush, and fog fruit.

Portions of the area between the proposed borrow area and Femme Osage Slough are identified by the NWI as forested, broad-leaved deciduous, palustrine wetland that is temporarily flooded (USFWS 1989). However, these areas, with the exception of the wetlands discussed above, do not exhibit indicators of wetland hydrology or dominance of hydrophytic vegetation; therefore, they would not be considered jurisdictional wetlands.

The second borrow area contains one wetland and portions of three additional wetlands. In addition, three wetlands are adjacent to the second borrow area. These wetlands are described below. A 0.19-ha (0.46-acre) palustrine persistent emergent wetland that is temporarily to seasonally flooded is located entirely within the area to be excavated. This jurisdictional wetland is typically inundated by shallow surface water early in the growing season; by mid-summer, however, no surface water is present. The hydrological sources for this wetland include surface water flow from the adjacent slope and groundwater discharge. The dominant species of the vegetation community include fox sedge, curly dock, rush, and bulrush.

Approximately 0.08 ha ( 0.2 acre) of a 0.37 -ha (0.92-acre) jurisdictional wetland lies within the southern portion of the second borrow area. Another $55.7 \mathrm{~m}^{2}\left(600 \mathrm{ft}^{2}\right)$ of this wetland lies within the boundaries of the proposed haul road. This palustrine persistent emergent wetland is temporarily to seasonally flooded. This wetland is typically inundated by shallow surface water early in the growing season; by mid-summer, however, no surface water is present. The hydrological sources for this wetland consist of surface water flow from the adjacent slope and groundwater discharge. The dominant plant species in this wetland include sedge, curly dock, flatsedge, blue vervain, and white avens. 
A forested intermittent drainage extends into the southeast portion of the second borrow area. The lower elevations of this drainage contain a 0.08 -ha (0.2-acre) jurisdictional wetland. Approximately 0.02 ha ( 0.05 acre) of this wetland lies within the area to be excavated. This wetland is a palustrine forested, broad-leaved deciduous, temporarily to seasonally flooded wetland. The dominant species of the vegetation community in this wetland include sycamore, box elder, sedge, poison ivy, and persimmon.

Approximately $18.6 \mathrm{~m}^{2}\left(200 \mathrm{ft}^{2}\right)$ of a $65-\mathrm{m}^{2}\left(700-\mathrm{ft}^{2}\right)$ jurisdictional wetland lies within the western side of the second borrow area. Another $23.2 \mathrm{~m}^{2}\left(250 \mathrm{ft}^{2}\right)$ of this wetland lies within the boundaries of the proposed haul road. This palustrine persistent emergent wetland is temporarily flooded. It is typically inundated by shallow surface water early in the growing season; by midsummer, however, no surface water is present. This wetland receives surface water flows from the surrounding area, as well as groundwater discharge. Most of this wetland lies within the transmission line right-of-way, and the soil contains a considerable amount of gravel near the surface. The dominant plant species in this wetland are sedge and spike rush.

A $12.1-\mathrm{m}^{2}\left(130-\mathrm{ft}^{2}\right)$ jurisdictional wetland lies just to the west of the second borrow area and within the boundaries of the proposed haul road. This palustrine persistent emergent wetland is temporarily flooded. Typically, it is inundated by shallow surface water early in the growing season; by mid-summer, however, no surface water is present. The hydrological sources for this wetland include surface water flow from the surrounding area and groundwater discharge. This wetland lies entirely within the transmission line right-of-way, and the soil contains a considerable amount of gravel near the surface. The dominant plant species in this wetland is spike rush.

A narrow intermittent riverine wetland lies approximately $6 \mathrm{~m}(20 \mathrm{ft})$ to the north of the second borrow area, is parallel to the borrow area boundary, and terminates in a palustrine forested wetland community. The jurisdictional portion of this drainage is approximately 0.04 ha ( 0.10 acre $)$ in size and supports sycamore, hackberry, manna grass, white avens, poison ivy, and spotted touchme-not. This drainage originates on the forested hill northeast of the borrow area.

A jurisdictional wetland, 0.08 ha (0.2-acre) in size, is located immediately to the west of

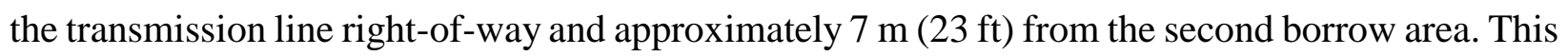
palustrine persistent emergent wetland is temporarily to seasonally flooded. It is inundated by shallow surface water early in the growing season; by mid- to late summer, however, no surface water is present. This wetland receives surface water flow from the surrounding area and groundwater discharge. The dominant plant species in this wetland include fox sedge, water plantain, and spike rush.

Soils in the area, including the second borrow area and nearby wetlands, are identified as Dockery Silt Loam (Tummons 1982). A seasonally high water table typically occurs at a depth of 0.30 to $1 \mathrm{~m}$ ( 1 to $3 \mathrm{ft}$ ) in Dockery soil (Tummons 1982). The groundwater level recorded in a test pit located within this borrow area was at a depth of $1.8 \mathrm{~m}(6 \mathrm{ft})$ in April 1989. 


\section{ANTICIPATED IMPACTS TO FLOODPLAINS AND WETLANDS}

\subsection{IMPACTS TO FLOODPLAINS}

\subsubsection{Impacts of the Proposed Action}

The Missouri River 100-year floodplain would be disturbed during excavation of the primary borrow area. Good engineering practices would be employed to control erosion and sedimentation to downstream surface waters and adjacent floodplain areas. Sediment and erosion controls such as silt fencing and hay bales would prevent disturbance to adjacent areas of the floodplain. Excavated areas would be graded to avoid steep or vertical slopes. Impacts to the floodplain would be minimized by the avoidance (to the extent practicable) of adjacent floodplain areas. No long-term adverse impacts are anticipated to the 100-year floodplain of the Missouri River. The proposed excavation would not adversely impact floodplain storage capacity and may result in a negligible increase in storage capacity. No permanent aboveground structures would be constructed within the floodplain.

\subsubsection{Impacts of the No Action Alternative}

No impacts to the flood storage capacity of the Missouri River 100-year floodplain would be expected under the No Action Alternative. No impacts to the floodplain are expected other than those resulting from naturally occurring events or non-DOE activities.

\subsection{IMPACTS TO WETLANDS}

\subsubsection{Impacts of the Proposed Action}

Excavation of the primary borrow area would result in the excavation of all but $40 \mathrm{~m}^{2}$ $\left(430 \mathrm{ft}^{2}\right)$ of a 0.69 -ha (1.7-acre) palustrine forested wetland. The remainder of this wetland would likely lose wetland functions as a result of its subsequent elevation above the surrounding landscape. However, if the hydrologic regime of Femme Osage Slough remains similar to historical patterns, seasonal surface inundation may continue to occur in this area.

Hydrology in the vicinity of the borrow area may change as a result of the excavation, and hydrologic characteristics of nearby wetlands may be adversely affected. The frequency or duration of flooding or soil saturation may be reduced within the adjacent wetland northeast of the borrow 
area, or within the forested wetland to the southwest. These wetland areas may no longer remain sites of surface water accumulation or groundwater discharge, and wetland functions may be lost. Surface inundation may continue to occur for brief periods in these wetlands, however, because of the high clay content and slow permeability of the soils in these areas. Wetland communities may change as species that are adapted to saturated soil conditions are replaced by upland species or species tolerant of a wider range of soil moisture conditions.

Surface water elevations in Femme Osage Slough may be initially reduced if seepage occurs from the slough into the borrow pit. Although Femme Osage Slough is considered to be a source of recharge to the groundwater system within the floodplain alluvium (Imes and Kleeschulte 1997), the rate of flow is believed to be quite low because of the slow permeability of the adjacent soils. The water surface elevation in the slough is typically located at a level equal to, or below, the projected depth of excavation within the primary borrow area. Most of the borrow area would be excavated to an elevation of 137.5 to $138.1 \mathrm{~m}$ (451 to $453 \mathrm{ft}$ ) AMSL, although a small area near the slough would be excavated below $137.5 \mathrm{~m}(451 \mathrm{ft})$. Water surface elevations in the slough generally range from 137.2 to $137.8 \mathrm{~m}$ (450 to $452 \mathrm{ft}$ ) AMSL. Seepage losses from the slough would, therefore, likely be limited to the lower portion of the borrow area. Water introduced into the borrow pit from the slough would eventually reach an equilibrium with water accumulated from surface water and groundwater sources.

Excavation of the second borrow area would result in the excavation of a wetland 0.19 ha ( 0.46 acre) in size, as well as portions of three other wetlands. The total wetland area that would be excavated within this borrow area is 0.29 ha $(0.72$ acre $)$. Approximately $79.0 \mathrm{~m}^{2}\left(850 \mathrm{ft}^{2}\right)$ of two of these emergent wetlands, plus an additional $12.1 \mathrm{~m}^{2}\left(130 \mathrm{ft}^{2}\right)$ wetland, would be covered with gravel during construction of the haul road.

Adjacent to this borrow area, a 0.04-ha (0.10-acre) forested intermittent riverine wetland lies just to the north, and a 0.08-ha (0.2-acre) palustrine emergent wetland lies just to the west. Hydrology in the vicinity of this borrow area also may change as a result of the excavation. Hydrologic characteristics within the remainder of partially excavated wetlands and of the other nearby wetlands may be adversely affected. The frequency or duration of flooding may be reduced within the adjacent wetland west of the borrow area or within the forested wetland to the north. Consequently, these wetland areas may no longer remain sites of surface water accumulation or groundwater discharge, and wetland functions may be lost. Surface inundation may continue to occur for brief periods, however, because of the moderate permeability of the soils in these areas. Wetland communities may change as species that are adapted to saturated soil conditions are replaced by upland species or species tolerant of a wider range of soil moisture conditions. 


\subsubsection{Impacts of the No Action Alternative}

No direct impacts to wetlands would be expected under the No Action Alternative.

\subsection{MITIGATION AND PERMITTING}

The affected wetlands are considered waters of the United States, and, therefore, are under the jurisdiction of Section 404 of the CWA. DOE has initiated consultations with the U.S. Army Corps of Engineers for a determination of the permits and conditions that would be required for compliance with Section 404. A storm water control plan would be implemented to prevent sedimentation and erosion impacts to adjacent floodplain areas and surface waters. Good engineering practices would be employed to control erosion and sedimentation to downstream surface waters. 


\section{CONCLUSIONS}

Approximately 0.69 ha (1.7 acres) of wetland would be excavated during development of the primary borrow area, and 0.29 ha ( 0.72 acre) of wetland would be excavated during development of the second borrow area, if utilized, resulting in 0.98 ha ( 2.4 acres) of total wetland excavation. In addition, 0.01 ha ( 0.02 acre) of wetland would be covered during construction of the haul road for the second borrow area, if utilized. The proposed action would not be expected to result in adverse impacts to the Missouri River 100-year floodplain. Hydrologic characteristics within nearby wetlands may be altered because of potential changes in surface water or groundwater hydrology. The borrow areas would likely become areas of surface water and groundwater accumulation, and wetland characteristics may subsequently develop within these areas. 


\section{REFERENCES}

Cowardin, L.M., et al., 1979, Classification of Wetlands and Deepwater Habitats of the United States, FWS/OBS-79/31, U.S. Fish and Wildlife Service, Washington, DC.

Environmental Laboratory, 1987, Corps of Engineers Wetlands Delineation Manual, Technical Report Y-87-1, U.S. Army Engineer Waterways Experiment Station, Vicksburg, MS.

Federal Emergency Management Agency (FEMA), 1992, Flood Insurance Rate Map, St. Charles County, Missouri, and Incorporated Areas, Panel 100, Washington, DC.

Tummons, R. L., 1982, Soil Survey of St. Charles County, Missouri, U.S. Department of Agriculture, Soil Conservation Service.

U.S. Fish and Wildlife Service (USFWS), 1989, National Wetlands Inventory Map, Defiance, MO, Quadrangle, U.S. Department of the Interior, Fish and Wildlife Service, National Wetlands Inventory, St. Petersburg, FL.

Imes, J.L., and Kleeschulte, M.J., Ground-Water Flow and Ground- and Surface-Water Interaction at the Weldon Spring Quarry, St. Charles County, Missouri, Water-Resources Investigations Report 96-4279, U.S. Geological Survey, Rolla, MO. 
